\title{
Revolusi Pembelajaran Metodologi Ekonomi Selama Masa Pandemik Covid-19 Melalui Fitur "Tanya Egy”
}

\author{
Ermita Yusida*1, Vika Annisa Qurrata ${ }^{2}$ Linda Seprillina ${ }^{3}$ \\ 1,2,3 Fakultas Ekonomi, Universitas Negeri Malang \\ *e-mail: ermita.yusida.fe@um.ac.id¹ , vika.annisa.fe@um.ac.id ${ }^{2}$, linda.seprillina.fe@um.ac.id³
}

\begin{abstract}
The research methodology is a subject that has an essential role in completing the study. Authors provided an innovation called Tanya Egy, based on a website application for Question and Answer (Q\&A) about research methodology, both quantitative or qualitative. The Tanya Egy application has been synchronized with SPEDOL (Economic Library Service System and Online Data), owned by the Department of Economic Development FE UM. In this application, there are also many lecturers with econometric expertise and lecturers with expertise in the field of qualitative research methods. This feature is not only for students who are taking research methods but also for students who are preparing a thesis. The result of this activity is that 23 students have used and asked questions online through the Ask Egy feature. As many as 80 percent of students said this feature was beneficial in completing their thesis.
\end{abstract}

Keywords: learning innovation, learning revolution, Tanya Egy, research method

\begin{abstract}
Abstrak
Metodologi penelitian merupakan matakuliah yang memiliki peranan penting dalam penyelesaian studi. Penemuan inovasi aplikasi "Tanya Egy" merupakan fitur yang berupa website khusus untuk Tanya jawab permasalahan metodologi penelitian secara kuantitatif dan kualitatif. Aplikasi Tanya Egy telah tersinkronisasi dengan SPEDOL (Sistem Pelayanan Pustaka Ekonomi dan Data Online) yang telah dimiliki oleh jurusan Ekonomi Pembangunan FE UM. Dalam aplikasi ini juga tergabung banyak dosen dengan keahlian ekonometrika maupun dosen dengan keahlian di bidang metode penelitian kualitatif. Fitur ini tidak hanya untuk mahasiswa yang sedang menempuh metode penelitian namun juga untuk mahasiswa yang akan menyiapkan skripsi atau mahasiswa yang saat ini berada diambang kebingungan dalam penyelesaian skripsi. Hasil dari kegiatan ini yaitu terdapat sebanyak 23 mahasiswa yang sudah memanfaatkan dan bertanya secara daring melalui fitur Tanya Egy. Kemudian sebanyak 80 persen mahasiswa mengatakan bahwa fitur ini sangat membantu dalam penyelesaian skripsi.
\end{abstract}

Kata kunci: inovasi pembelajaran, metodologi penelitian, revolusi pembelajaran, Tanya Egy

\section{PENDAHULUAN}

Solusi dalam penyelesaian permasalahan yang disusun dalam sebuah penelitian atau tulisan yaitu dengan menggunakan metodologi penelitian. Dalam sebuah perguruan tinggi, metode penelitian merupakan suatu hal yang harus dikuasi oleh mahasiswa untuk menyelesaikan studi mereka di mana setiap sarjana dapat dikatakan lulus apabila sudah menyelesaikan skripsi. Sedangkan salah satu alat untuk menyelesaikannya yaitu tergantung pada metode penelitian yang mereka ambil.

Selama menempuh kuliah, mahasiswa di Jurusan Ekonomi Pembangunan FE UM akan menempuh matakuliah metodologi penelitian selama satu semester. Pada satu semester tersebut mahasiswa dituntut untuk memahami metode penelitian kualitatif dan metode penelitian kuantitatif. Tentu ini menjadi momok tersendiri bagi mahasiswa, terutama di masa Pandemik Covid-19 seperti sekarang. Dalam upaya memutus penyebaran rantai virus, Menteri Pendidikan dan Kebudayaan dalam Surat Edaran (SE) Nomor 4 Tahun 2020 tanggal 24 Maret 2020, yang menganjurkan kegiatan belajar yang mencakup sekolah dan perguruan tinggi untuk belajar di rumah via daring. Maka, kesulitan mahasiswa akan semakin menumpuk.

Selain itu tipe mahasiswa yang hanya mengambil skripsi dengan melihat skripsi kakak tingkatnya membuat skrispi dan karya ilmiah mahasiswa menjadi tidak bervariatif sehingga kualitas tulisan mahasiswa dapat dikatakan masih rendah. Hal ini dikarenakan mahasiswa tidak 
memahami variasi metode penelitian secara menyeluruh dan detail. Di samping itu, ketakutan mahasiswa yang dikarenakan tidak mendapatkan bimbingan mengenai metode yang digunakan mahasiswa juga membuat mahasiswa urung dalam mengambil metodologi yang baru dan beda.

Apabila hal ini terus terjadi maka kelulusan mahasiswa menjadi tertunda, artinya mahasiswa tidak dapat lulus tepat waktu. Tentunya juga akan berpengaruh pada nilai akreditasi jurusan. Oleh karena itu, dari latar belakang pandemi yang mengharuskan physical distancing dan kebutuhan konsultasi metodologi yang juga penting maka pembelajaran dalam jaringan atau daring (online) dapat menjadi satu alternatif untuk diterapkan (Nugrahani, Egar, \& Musarokah, 2020; Subekti \& Kurniawati, 2020). Untuk mendukung pemahaman mahasiswa mengenai metodologi penelitian maka pengusul kegiatan membuat fitur "Tanya Egy" sebagai revolusi pembelajaran metode penelitian berbasis m-learning. Metode dan inovasi pembelajaran berbasis m-learning interactive memungkinkan pembelajaran dilakukan secara berkesinambungan tanpa terbatas oleh ruang dan waktu (Bintoro \& Zuliana, 2015). Selain itu, pemanfaatan teknologi pada kegiatan pembelajaran juga dapat mendorong minat siswa dalam belajar dan memudahkan pendidik dalam menyampaikan materi (Barovih \& Sugara, 2020).

Definisi m-learning telah berkembang dalam berbagai cara dan arah sejak dekade pertama tahun 2000-an. Menurut (Baran, 2014), evolusi definisi-definisi ini terutama menyoroti karakteristik positif m-learning seperti mobilitas (Sharples \& Pea, 2014), akses (Parsons, Ryu, \& Cranshaw, 2006), kedekatan (Seppälä \& Alamäki, 2003), situativitas (Cheon, Lee, Crooks, \& Song, 2012), di mana-mana (Warsita, 2018), kenyamanan (Seppälä \& Alamäki, 2003), dan kontekstualitas (Kearney, Schuck, Burden, \& Aubusson, 2012).

Penekanan berbeda ini mencerminkan dampak yang diharapkan tetapi juga tak terduga dari pengenalan teknologi digital ini dalam proses pembelajaran. Dalam sejarah m-learning, definisi awal lebih digerakkan oleh perangkat (berfokus pada kedekatan, kenyamanan, akses dan mobilitas) sedangkan yang terakhir lebih bersifat pribadi dan sosial, mengeksplorasi biaya yang berkaitan dengan fitur teknologi baru dari perangkat seluler seperti sebagai kesadaran lokasi, deteksi gerakan dan augmented reality (Baran, 2014).

Pemanfaatan m-learning menjadi tantangan terbaru dari perkembangan pendidikan di bidang teknologi dan informasi (Khan, Al-Shihi, Al-Khanjari, \& Sarrab, 2015). Hal ini ditunjukkan bahwa negara maju seperti Korea Selatan, Amerika Serikat, Jepang, Taiwan, Singapura, Malaysia, Uni Eropa dan Australia telah menggunakan perangkat mobile di sektor pendidikan. Namun beberapa negara berkembang seperti Indonesia masih mengalami kendala dalam pengembangan m-learning (Husna, 2020). Belum meratanya masyarakat yang melek teknologi serta infrastruktur internet membuat masalah ini kian rumit. Mobile learning memiliki dampak signifikan dalam mendorong kemandirian siswa yang berujung pada hasil belajar peserta didik (Rahmawati \& Mukminan, 2018; Efendi, Lusi, \& Romet, 2019).

Tujuan dari adanya pengabdian ini yaitu memberikan solusi permasalahan yang dihadapi oleh mahasiswa yaitu melalui revolusi pembelajaran metode penelitian melalui fitur "Tanya Egy" yang berbasis website. Manfaat dari fitur ini yaitu mahasiswa dapat bebas bertanya mengenai metode penelitian baik yang bersifat kualitatif maupun kuantitatif. Dosen-dosen yang menjawab merupakan dosen-dosen dengan keahlian ekonometrika maupun dosen dengan keahlian di bidang metode penelitian kualitatif. Sehingga fitur ini tidak hanya untuk mahasiswa yang sedang menempuh metode penelitian namun juga untuk mahasiswa yang akan menyiapkan skripsi atau mahasiswa yang saat ini berada diambang kebingungan dalam penyelesaian skripsi.

\section{METODE}

Kegiatan pengabdian ini dilakukan dengan metode pendekatan ADDIE (Analysis, Design, Develop, Implementation, andEvaluation). Menurut Salas-Rueda et al. (2020), model ADDIE merupakan inti perancangan instruksional dan menjadi dasar system perancangan instruksional (Instructional System Design-ISD). Tahapan pelaksanaan akan secara rinci diperlihatkan pada 
Gambar 1. Gambar ini akan berisi tentang tahapan analisa, desain, pengembangan, implementasi dan evaluasi. Tahap analisis, terdiri atas identifikasi kebutuhan mahasiswa dan dosen, identifikasi permasalahan, dan identifikasi kebutuhan pengguna. Selain itu pada tahap ini mengkaji konsepkonsep dan teori-teori yang berkenaan dengan model pembelajaran dengan e-learning berbasis smartphone, sedangkan survei lapangan dilaksanakan untuk pengumpulan data yang berkenaan dengan mahasiswa, dosen, kurikulum, metode, media, sumber belajar, dan sarana prasarana.

Tahap penyusunan konsep dimulai dengan membuat rancangan awal desain Tanya Egy yang mana fitur ini akan terintegrasi dengan SPEDOL (Sistem Pustaka dan Data Online) milik Jurusan Ekonomi Pembangunan. Setelah rancangan awal desain terpenuhi, maka akan dilakukan tahapan uji coba yang dimaksudkan untuk melihat kekurangan dalam fitur ini. Desain yang telah di uji coba tersebut akan di-link-kan dengan laman milik jurusan Ekonomi Pembangunan sehingga mahasiswa dapat mengakses dengan mudah dan gratis.

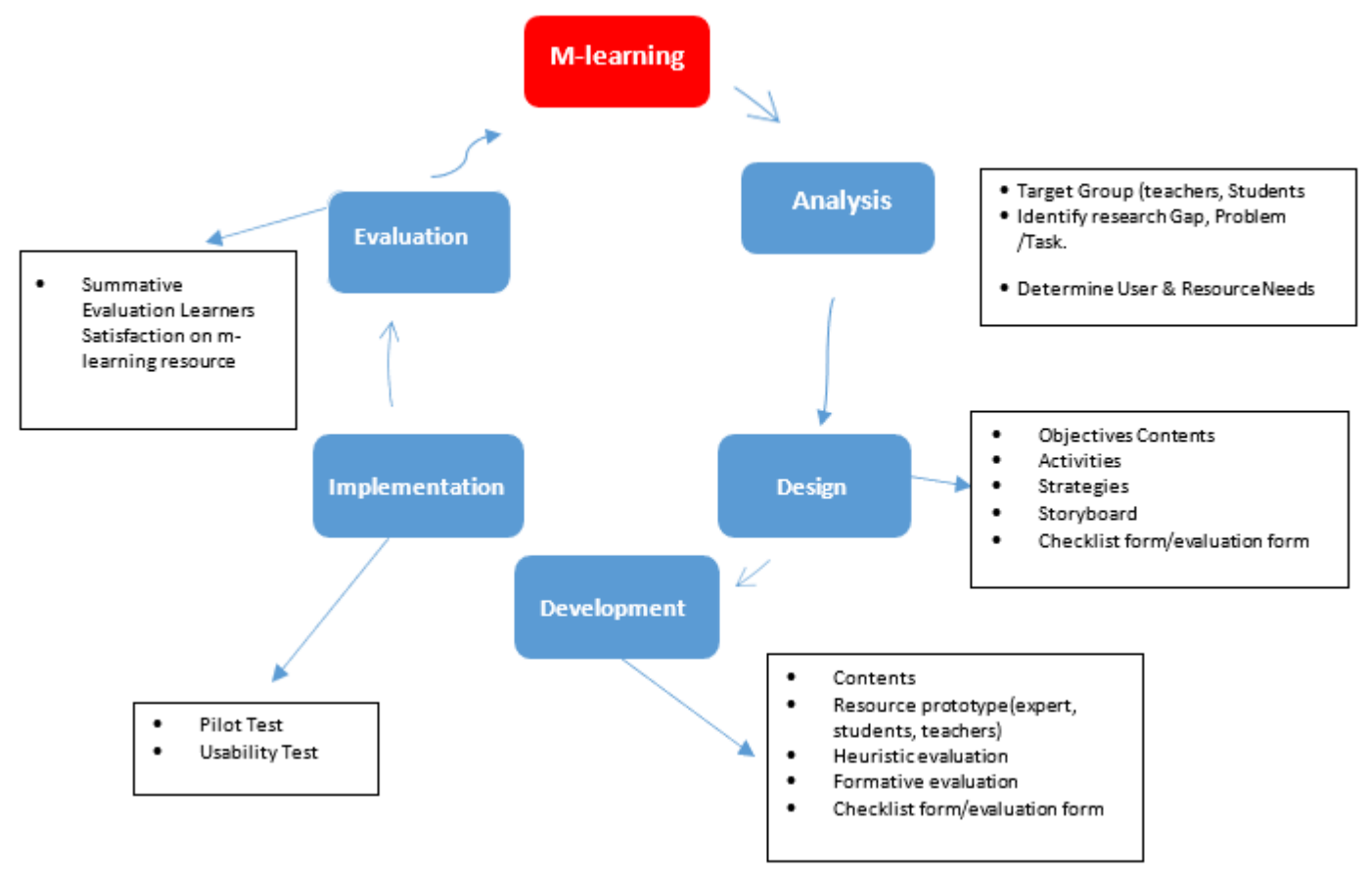

Gambar 1. Langkah-langkah penelitian

Tahap desain, dilakukan dengan rancangan program berdasarkan rancangan program berdasarkan hasil yang diperoleh dalam tahap analisis yang meliputi: tujuan pembelajaran, kegiatan, strategi, dan formulir evaluasi. Tahap implementasi dan evaluasi, hasil rancangan tersebut dituangkan implementasikan melalui website, sedangkan pengujian program dilakukan pada kelas kecil melalui pengguna berdasarkan kegunaan, kemudahan penggunaan, kemudahan belajar dan tingkat kepuasan mahasiswa. Hasil pembuatan prototype akan mengambil sample 75 mahasiswa, ahli media pembelajaran dan ahli materi untuk mengoperasikannya. Pengujian ini akan membutuhkan fitur Tanya Egy yang terintegrasi dengan SPEDOL dan mencoba semua fitur yang ada. Data pengujian yang sudah dilakukan, dicatat dan dijadikan sebagai bahan evaluasi dalam perbaikan. Evaluasi diadakan apabila terdapat kekurangan ekurangan atau masukkan dari semua pengguna. Langkah terakhir yaitu penyempurnaan desain dan fitur-fitur yang ada di website.

\section{HASIL DAN PEMBAHASAN}

\subsection{Deskripsi Proses Pengembangan Aplikasi Tanya Egy}

Beberapa tahapan dalam pengembangan ini meliputi analisis, desain, pengembangan, implementasi, dan evaluasi. Tahapan yang telah dilakukan dari keseluruhan rangkaian tersebut 
adalah tahap ananalisis dan desain. Pada tahap analisis, dosen melakukan identifikasi permasalahan tentang kesulitan dalam menempuh skripsi. Identifikasi dilakukan melalui diskusi dan voting dengan mahasiswa, tentang kendala dalam proses skripsi. Dari kendala tersebut, sebagian besar berupa kesulitan dalam memahami alat analisa dan membaca data yang telah didapatkan dari proses penelitian. Solusi dari kendala tersebut adalah membuat rancangan untuk memudahkan mahasiswa dalam bertanya mengenai metode penelitian baik yang bersifat kualitatif maupun kuantitatif. Aplikasi ini berbasis website, sehingga mahasiswa dapat bertanya kepada dosen pilihan mereka dimanapun dan kapanpun.

Selanjutnya, beberapa hal penting yang diperlukan adalah rancangan pengumpulan data mengenai tema dan sub bahasan dalam Tanya Egy. Selain itu, tim pengabdian juga mengumpulkan dosen-dosen yang bersedia menjawab pertanyaan di Tanya Egy. Pada tahapan desain, tim pengabdian bekerjasama dengan developer aplikasi menyusun konsep website Tanya Egy menggunakan aplikasi eXelearning dan Phone Gap. Tahapan ini dilakukan melalui kerjasama dengan ahli IT, untuk membuat tampilan website yang memudahkan pengguna.

\subsection{Hasil Uji Coba Produk Inobel}

Sebagai salah satu bentuk pengembangan dari aplikasi Tanya Egy, tim pengembang telah melakukan evaluasi terhadap produk. Evaluasi ini dilakukan dengan metode survey online dengan membuat kuisioner online pada google form. Hasil survey menunjukkan terdapat 75 responden yang mengisi kuisioner tingkat kepuasan aplikasi Tanya Egy. Sebanyak 75 responden yang mengisi hasil kuisioner Sebagian besar yaitu perempuan, sebanyak 74.7 persen dan semua responden adalah mahasiswa Universitas Negeri Malang. Segmentasi utama produk Tanya Egy ini yaitu untuk mahasiswa yang sedang menempuh skripsi. Sehingga aplikasi ini memang banyak digunakan oleh mahasiswa tingkat akhir. Hal ini terbukti dengan hasil kuisioner yang 48 persennya diisi oleh mahasiswa yang sedang menempuh skripsi. Secara lebih detail, hasil survey evaluasi produk Tanya Egy dapat dilihat pada Gambar 2.

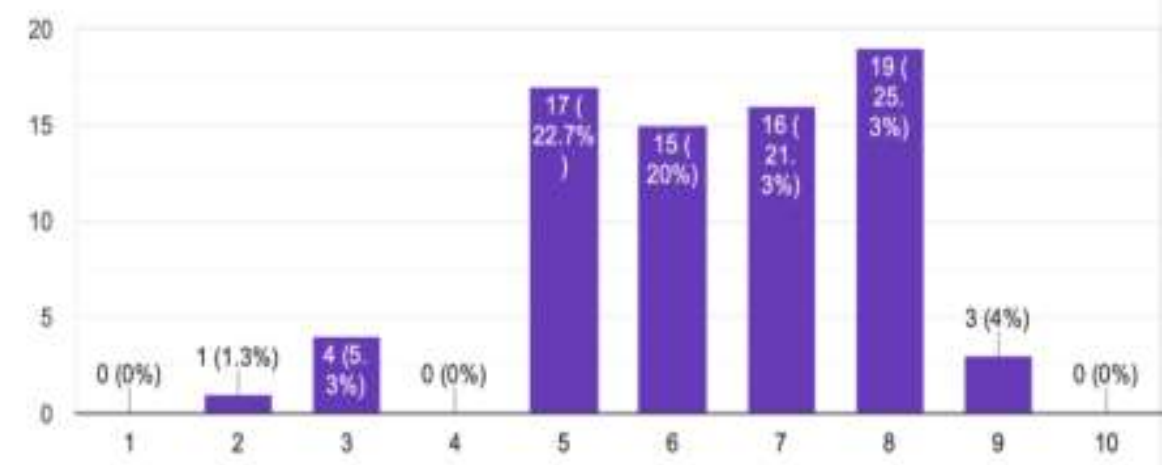

Gambar 2. Tingkat kesulitan pengerjaan metodologi penelitian

Gambar 2 menjelaskan bahwa tingkat kesulitan pengerjaan metodologi penelitian cukup tinggi. Dimana 46 persen lebih mahasiswa menyatakan nilai di atas 5 pada poin tingkat kesulitan mahasiswa. Rata-rata mahasiswa menggunakan aplikasi Tanya Egy kurang dari 3 bulan. Hal ini dikarenakan aplikasi ini memang masih baru. Selain itu aplikasi ini dirasa sangat nyaman untuk digunakan. 70 persen mahasiswa menyatakan nilai rata-rata 8 untuk poin kenyamanan dalam penggunaan aplikasi Tanya Egy. Disamping itu, kesulitan materi Metodologi Penelitian ini dapat diatasi dengan adanya aplikasi Tanya Egy. Hasil survey menunjukkan sebanyak 75 persen lebih mahasiswa menyatakan bahwa aplikasi Tanya Egy dalam membantu materi perkuliahan. Hal ini membuat 80 persen mahasiswa menjadi lebih mudah memahami Metodologi Penelitian. 
Apabila dilihat dari tingkat kepuasan mahasiswa, 90 persen lebih mahasiswa menyatakan sangat puas terhadap kelengkapan konten aplikasi Tanya Egy dalam menampilkan data serta menyelesaikan proses skripsi mereka (Gambar 3).

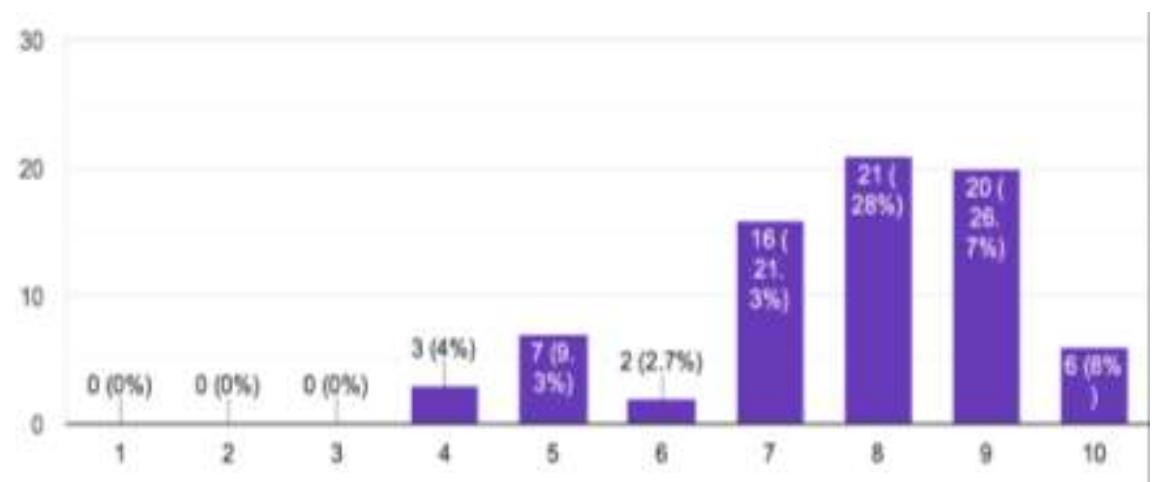

Gambar 3. Peran aplikasi 'Tanya Egy' dalam menyelesaikan skripsi

Selanjutnya kepuasan mahasiswa terhadap aplikasi Tanya Egy juga dikarenakan aplikasi data dapat digunakan secara online dan offline. Secara lebih rinci dapat dilihat pada Gambar 4.

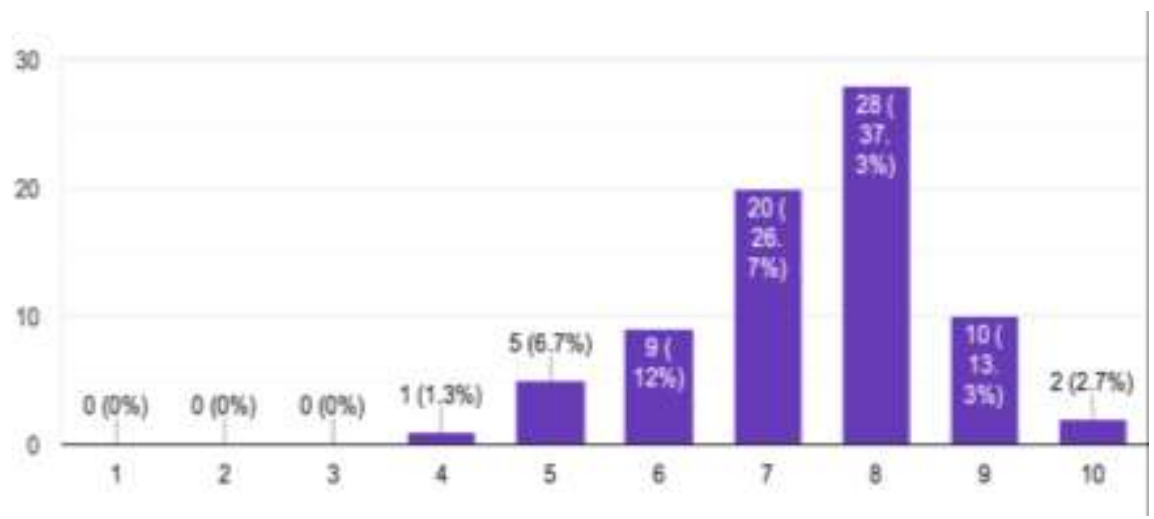

Gambar 4. Kepuasan Mahasiswa terhadap konten aplikasi 'Tanya Egy'

Selanjutnya hasil survey menunjukkan bahwa 95 persen mahasiswa sangat senang karena aplikasi Tanya Egy dapat digunakan secara online. Sehingga bagi mahasiswa yang dapat mengakses aplikasi Tanya Egy dimanapun dan kapanpun. Menarik lagi, Gambar 5 menunjukkan bahwa 90 persen responden yang terdiri dari mahasiswa menyatakan bahwa fitur aplikasi Tanya Egy mudah dipahami dan digunakan. Hal ini membuat mahasiswa tidak bosan dalam mengoperasionalkan Tanya Egy.

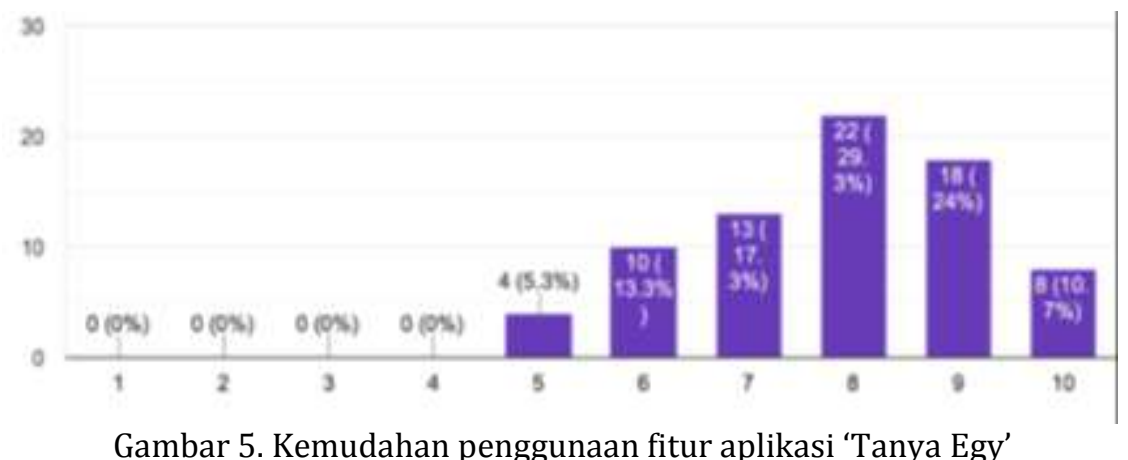

Gambar 6 menyatakan bahwa sebanyak 38.7 persen mahasiswa menyatakan akan selalu menggunakan aplikasi Tanya Egy dalam mempelajari Metodologi Penelitian. Sedangkan 60 persen responden menyatakan kadang-kadang menggunakan aplikasi, sisanya tidak pernah. Hal ini mengindikasikan bahwa Tanya Egy digunakan sebagai aplikasi yang merupakan acuan apabila 
mahasiswa kesulitan memahami terminologi Metodologi Penelitian dalam waktu singkat. Sedangkan yang menjawab tidak pernah merupakan mahasiswa yang tidak sedang menempuh skripsi.

Selanjutnya 76 persen mahasiswa menyatakan bahwa aplikasi Tanya Egy perlu dikembangkan dengan fitur tambahan. Hal ini nantinya tidak hanya menjadi aplikasi tanya jawab namun lebih pada buku Metodologi Penelitian yang dapat diakses secara online (Gambar 7). Oleh karena itu pengembangan terhadap aplikasi ini sangat diperlukan.

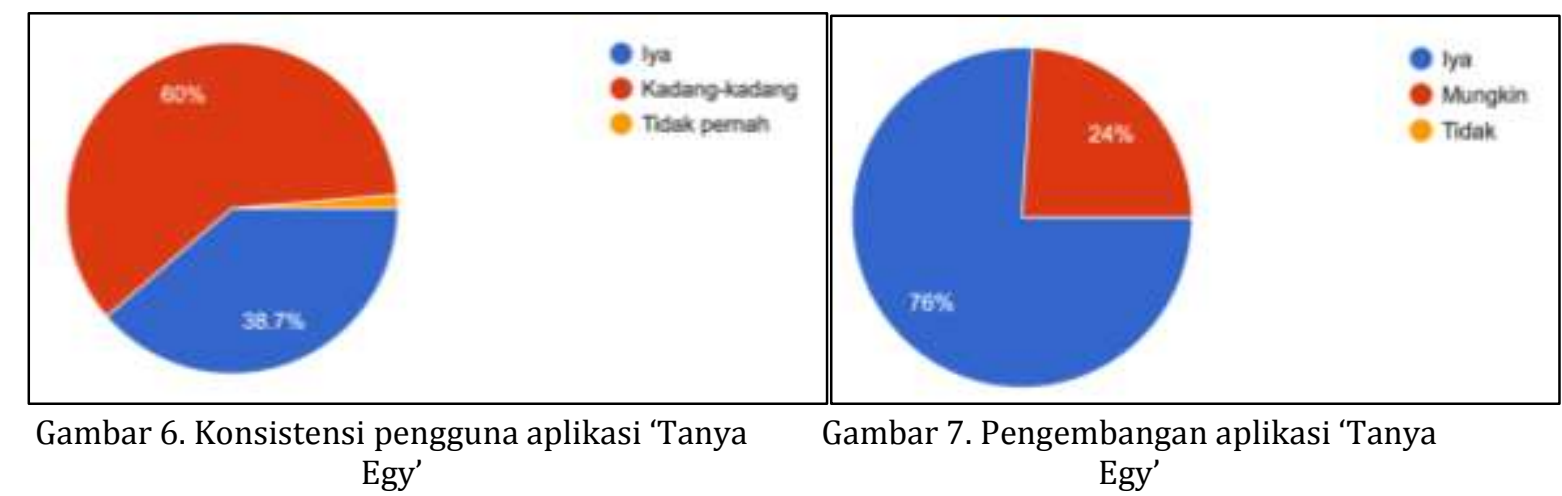

Berdasarkan Gambar 8, terdapat 65 persen mahasiswa yang menyatakan bahwa respon aplikasi Tanya Egy sangat cepat dalam m erespon permintaan pengguna. Hal ini mengindikasikan masih ada beberapa pengguna yang merasakan lambat respon aplikasi. Kelambatan aplikasi ini juga dipengaruhi oleh penangkapan signal masing-masing pengguna.

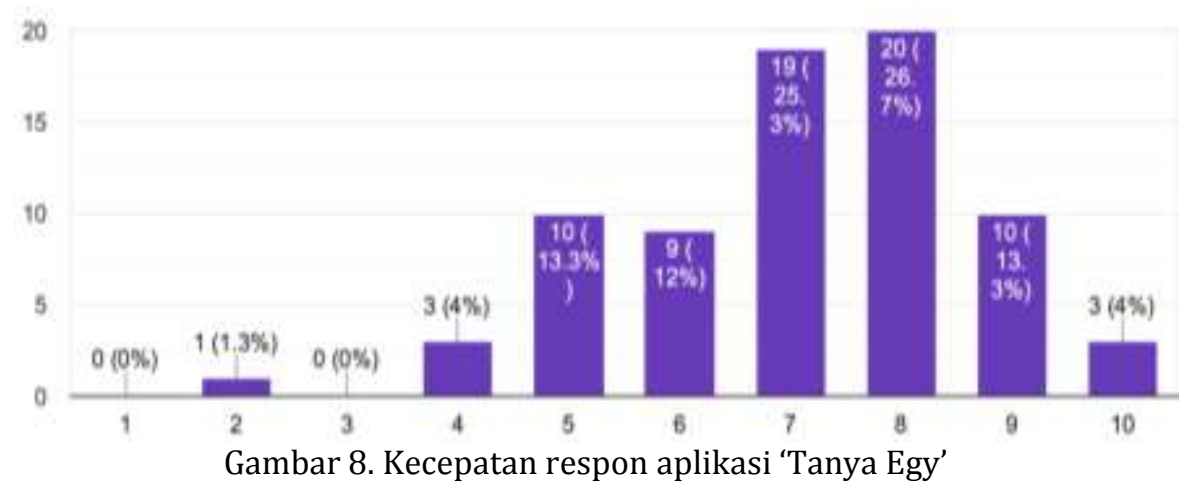

Terakhir, sebanyak 50 persen lebih responden menyatakan bahwa tampilan aplikasi Tanya Egy membuat pengguna lebih nyaman dalam penggunaan aplikasi ini.

\subsection{Deskripsi Produk Inobel}

Keterbaruan inovasi pada Tanya Egy dalam dunia pendidikan khususnya dalam metode pembelajaran yang menggunakan individu learning. Dengan adanya Tanya Egy, mahasiswa dapat berkonsultasi tentang metodologi penelitian secara langsung pada dosen-dosen yang tergabung dalam aplikasi ini. Aplikasi ini juga memiliki simpanan data tentang pertanyaan yang sering diajukan oleh mahasiswa sehingga pengguna tidak perlu bertanya lagi jika pertanyaan mereka sudah ada.

Penggunaan aplikasi ini sangat mudah karena akan bisa mereka akses secara gratis diwebsite www.spedol.com. Aplikasi tanya jawab seperti ini sudah banyak ditemukan tetapi tidak ada yang menjawab pertanyaan tentang metodologi penelitian khususnya di Ekonomi. Aplikasi ini berbentuk online, sehingga memudahkan pengguna untuk mengakses setiap saat. 


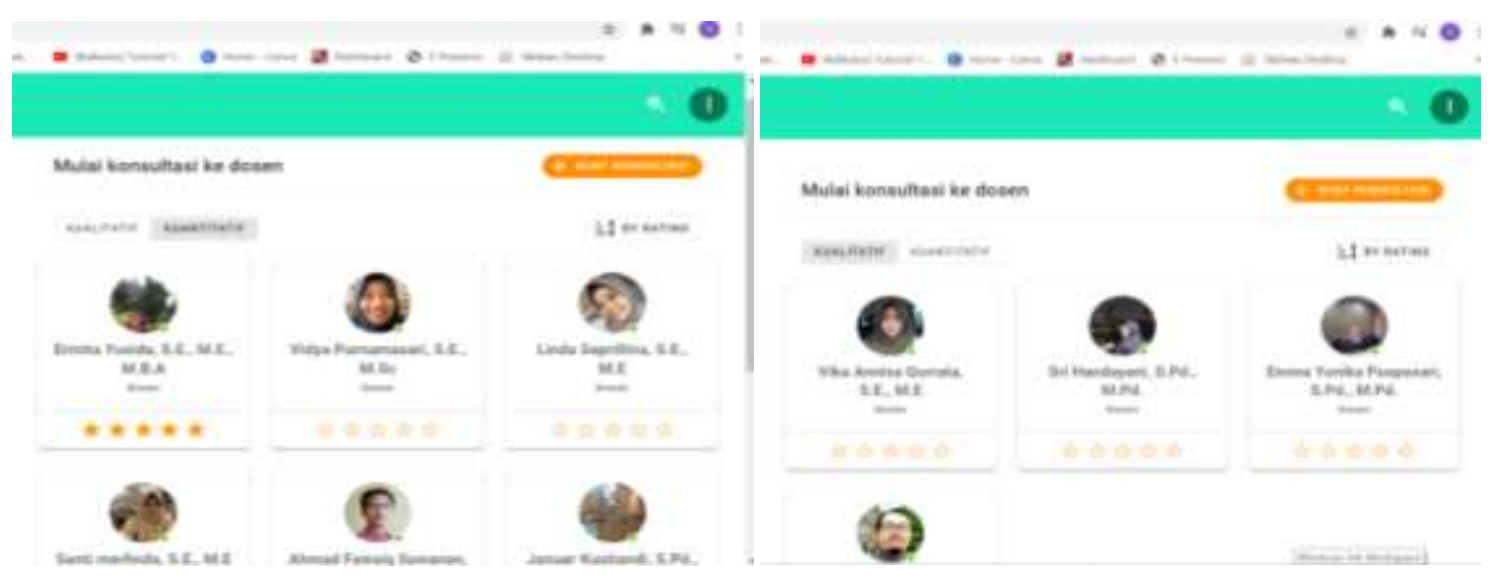

Gambar 9. Tampilan dosen-dosen kuantitatif dan kualitatif

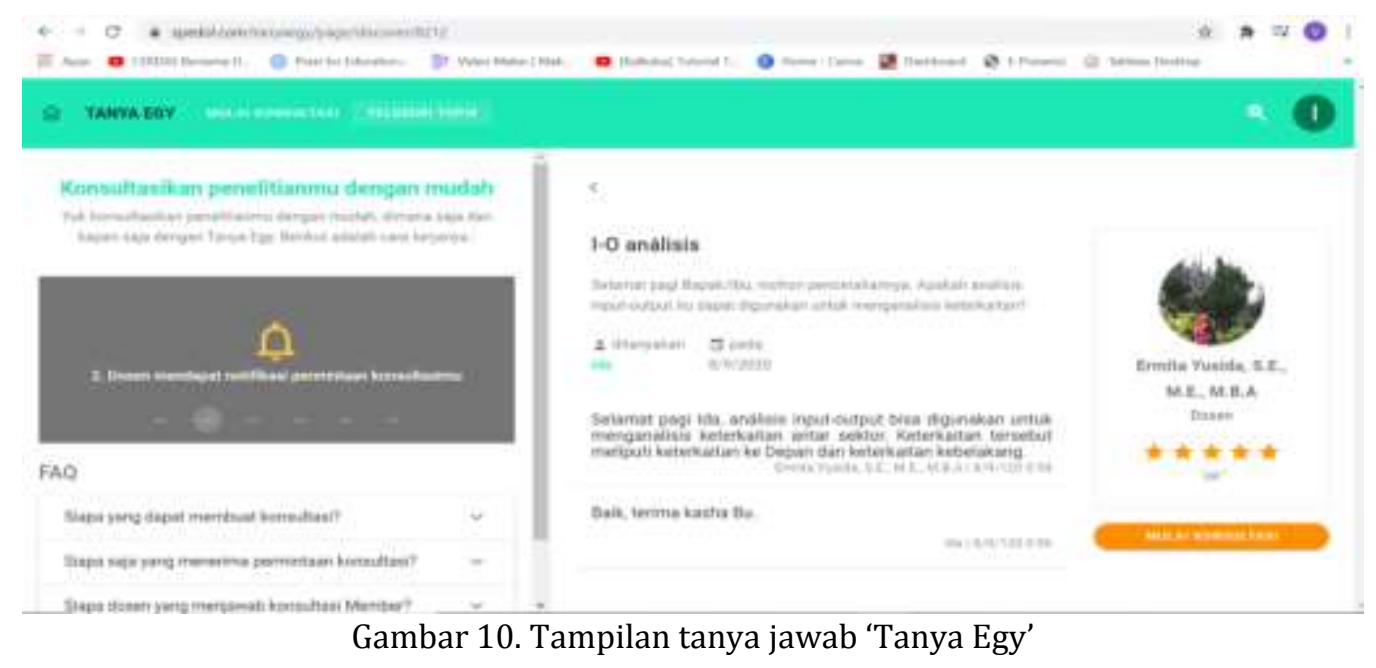

Setelah pengguna mengakses Tanya Egy melalui website Spedol.com, maka mereka langsung bisa menggunakan aplikasi tersebut. Untuk masuk ke dalam Tanya Egy, mereka diwajibkan sign up terlebih dahulu melalui e-mail. Hal ini tidak membatasi siapapun dalam menggunakan dan mengaplikasi kan Tanya Egy. Tampilan dalam Tanya Egy dibuat sederhana untuk memudahkan pengguna untuk melakukan konsultasi dengan dosen yang diinginkan. Pengguna memulai dengan cara mengklik fitur "mulai konsultasi". Setelah itu mereka tinggal mencari kolom "kualitatif" atau "kuantitatif". Dari pemilihan kolom tersebut, pengguna dapat mengklik "buat konsultasi". Apabila pengguna merasa kesulitan, ada kolom FAQ berisi tentang beberapa pertanyaan yang sering ditanyakan oleh pengguna.

\section{KESIMPULAN}

Inovasi pengembangan dan proses pembelajaran penting dilakukan, salah satunya dalam metodologi penelitian. Hal tersebut disebabkan banyaknya mahasiswa yang merasa kesulitan untuk menentukan desain metodologi penelitan skripsi mereka. Salah satu upaya inovasi yang dilakukan adalah pembuatan Aplikasi Tanya Egy untuk mempermudah mahasiswa dalam bertanya tentang metodologi penelitian yang akan mereka gunakan. Aplikasi ini menyajikan fitur konsultasi tentang metodologi penelitian. Berdasarkan hasil uji coba produk, sebanyak 80 persen responden yang terdiri dari mahasiswa yang sedang menempuh skripsi menyatakan produk ini sangat layak dalam mempermudah mereka dalam proses penyelesaian skripsi. Akan tetapi, perlu penambahan fitur untuk lebih memudahkan mahasiswa dalam menyelesaikan studi mereka. 


\section{UCAPAN TERIMA KASIH}

Penulis mengucapkan terima kasih kepada LP2M Universitas Negeri Malang yang telah memberi dukungan moral dan dana PNBP terhadap program pengabdian masyarakat ini.

\section{DAFTAR PUSTAKA}

Baran, E. (2014). A review of research on mobile learning in teacher education. Educational Technology and Society, 17(4), 17-32.

Barovih, G., \& Sugara, E. P. A. (2020). Pemanfaatan aplikasi sebagai media bantu edukasi agama islam untuk anak usia dini. Dinamisia: Jurnal Pengabdian Kepada Masyarakat, 4(1), 152-160. https://doi.org/10.31849/dinamisia.v4i1.3339

Bintoro, H. S., \& Zuliana, E. (2015). Penerapan interactive multimedia berbasis kurikulum 2013 ditinjau dari kecerdasan intrapersonal siswa pada pembelajaran Matematika SD. Kreano, $\begin{array}{llll}\text { Jurnal Matematika } & \text { Kreatif-Inovatif, } & 6(2), & 121-126 .\end{array}$ https://doi.org/10.15294/kreano.v6i2.4683

Efendi, Y., Lusi, L., \& Romet, R. M. (2019). Workshop mobile learning menuju sekolah berbasis digital pada SMK Negeri 1 Siak Kecil. Dinamisia: Jurnal Pengabdian Kepada Masyarakat, 3(1), 142-146.

Cheon, J., Lee, S., Crooks, S. M., \& Song, J. (2012). An investigation of mobile learning readiness in higher education based on the theory of planned behavior. Computers and Education, 59(3), 1054-1064 https://doi.org/10.1016/j.compedu.2012.04.015

Husna, R. (2020). Efektivitas Pembelajaran turunan pada masa pandemi Covid-19 melalui media mobile learning ditinjau dari hasil belajar mahasiswa. Numeracy, 7(2), 324-333.

Kearney, M., Schuck, S., Burden, K., \& Aubusson, P. (2012). Viewing mobile learning from a pedagogical perspective. Research in Learning Technology, 20(1), 1. https://doi.org/10.3402/rlt.v20i0/14406

Khan, A. I., Al-Shihi, H., Al-Khanjari, Z. A., \& Sarrab, M. (2015). Mobile learning (M-Learning) adoption in the Middle East: Lessons learned from the educationally advanced countries. Telematics and Informatics, 32(4), 909-920. https://doi.org/10.1016/j.tele.2015.04.005

Nugrahani, D., Egar, N., \& Musarokah, S. (2020). Pembelajaran daring pada pelatihan english for academic purpose universitas PGRI Semarang di masa pandemi Covid-19. Paedagoria: Jurnal Kajian, Penelitian dan Pengembangan Kependidikan, 11(2), 225-230.

Parsons, D., Ryu, H., \& Cranshaw, M. (2006). A study of design requirements for mobile learning environments. Proceedings - Sixth International Conference on Advanced Learning Technologies, ICALT 2006. https://doi.org/10.1109/icalt.2006.1652376

Rahmawati, E. M., \& Mukminan, M. (2018). Pengembangang m-learning untuk mendukung kemandirian dan hasil belajar mata pelajaran Geografi. Jurnal Inovasi Teknologi Pendidikan, 4(2), 157-166. https://doi.org/10.21831/jitp.v4i2.12726

Salas-Rueda, R. A., Salas-Rueda, É. P., \& Salas-Rueda, R. D. (2020). Analysis and design of the web game on descriptive statistics through the ADDIE model, data science and machine learning. International Journal of Education in Mathematics, Science and Technology, 8(3), 245260.

Seppälä, P., \& Alamäki, H. (2003). Mobile learning in teacher training. Journal of Computer Assisted Learning, 19(3), 330-335. https://doi.org/10.1046/j.0266-4909.2003.00034.x

Sharples, M., \& Pea, R. (2014). Mobile learning. The cambridge handbook of the learning sciences, Second Edition, (January), 501-521. https://doi.org/10.1017/CB09781139519526.030

Subekti, A. S., \& Kurniawati, L. A. (2020). Pelatihan mendesain pembelajaran daring menarik selama pandemi Covid-19 dengan teknologi pembelajaran sederhana. Dinamisia: Jurnal Pengabdian Kepada Masyarakat, 4(4), 588-595. https://doi.org/10.31849/dinamisia.v4i4.4679

Warsita, B. (2018). Mobile learning sebagai model pembelajaran yang efektif dan inovatif. Jurnal Teknodik, 14(1), 62-73. https://doi.org/10.32550/teknodik.v14i1.452 